\title{
오감과 영감을 활용한 감성북 편집디자인 연구 \\ Making an Emotional Design Book with 5 Senses and Inspiration -Focused on the Art Book 5+1(Five Plus One)-
}

\author{
홍동식 \\ 부경대학교 디자인학부 \\ Hong, Dong-Sik(ridersky@naver.com)
}

\section{요약}

$5+1$ (Five Plus One)은 오감 즉 시각, 청각, 후각, 미각, 촉각과 영감을 주제로 한 시각적 표현의 결과물이 다. 오감에 관한 자료를 찾아보았으나 과학적 근거와 다국적 언어들의 인용으로 된 자료들만 무성하였으며 시각적 유희와 감성의 표현으로 이루어진 예술적 표현과는 거리가 먼 서적들이 대부분이었다. 대부분 어린 이 지능발달을 위한 교재가 대부분이었으며 학술적 논문과 의학서적들이 주를 이루고 있다. 이에 한글과 영문을 혼용하여 가독성의 문제가 있어 이해되지 않은 상황에서도 오감과 영감에 관한 커뮤니케이션이 가 능한 감성북을 제작하였다. 연구 결과물은 오감과 영감을 시각화 시키는 작업에 중점을 두었다. 그리고 의 미와 각 감각의 이해도를 높이기 위한 기초과학 상식에 입각한 정보디자인의 제작, 각 감각의 시각적 증빙 을 위한 실험 등을 구사하였다. 그리고 각 감각을 구체화시키기 위해 사물과 의미 표현을 위한 촬영, 메타포 의 활용, 일러스트레이션 타이포그라피에 특히 역점을 두었다. 이러한 실험과 표현 방법을 통하여 제작과정 과 그리고 이러한 작업의 결과가 하나의 책으로 완성되어가는 결과물을 연구물로 제시하였다.

- 중심어 : | 타이포그라피 | 오감 | 영감 | 시각화 |

\section{Abstract}

'Five Plus One'is a result of visual expressions on five senses such as the sense of sight, hearing, smell, taste, and touch. Although I searched for the data on five senses, there were only information which was quoted in various languages and scientific bases, and also most of the books written were far from artistic expressions including visual pleasure and emotional expressions. In addition, most materials were mainly textbooks for children's intellectual development, academic papers, and medical publications.

Therefore, I made this book that makes us to communicate about five senses and an inspiration even though we have a problem to read writings in both Korean and English.

I arranged visual elements using illustrations and typography in various ways based on the scientific evidence.

keyword : | Typography | Five Senses | Inspiration I Visualization |

\section{Background of the Design}

'Five Plus One'is a result of visual expressions on five senses such as the sense of sight, hearing, smell, taste, and touch. Although I searched for the data on five senses, there were only information which was

* 이 논문은 2009학년도 부경대학교의 지원을 받아 수행된 연구임(PKS-2009-2)

접수번호 : \#100223-004

접수일자 : 2010년 02월 23일
심사완료일 : 2010년 04월 02일

교신저자 : 홍동식, e-mail : ridersky@naver.com 
quoted in various languages and scientific bases, and also most of the books written were far from artistic expressions including visual pleasure and emotional expressions. In addition, most materials were mainly textbooks for children's intellectual development, academic papers, and medical publications.

Therefore, I made this book that makes us to communicate about five senses and an inspiration even though we have a problem to read writings in both Korean and English.

The format of the book is $254 \mathrm{~mm} \times 178 \mathrm{~mm}$. It is made four-color print separations, and two more colors are added. Its paper is Courte fine matte $150 \mathrm{~g}$ and cover is $\mathrm{Hi}-\mathrm{Q}$ duo art paper $250 \mathrm{~g}$. The book is 516 pages long, except for the cover page. I expected it would be difficult to bind the book due to its thickness, but it was finished by saddle-stitched binding after 6 mid-bindings.

I focused on an editorial design as it was made. The sources and bases are precisely written to make definitions of five senses and the inspiration perfectly clear. Besides, it includes interviews from experts, and also contains the processes of experiments and its results. I made efforts to show abundant visual effects and information through the design approaches: 1. Scientific approach, 2. Common-sense

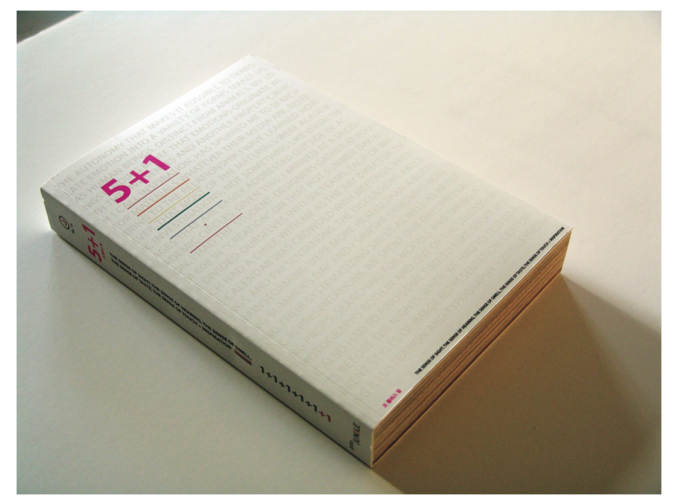

Fig 1. Published ' $5+1$ (Five Plus One)' approach, and 3. Emotional approach.

\section{The Concept of Design}

Five senses are made of the sense of sight, hearing, smell, taste, and touch, not including an inspiration. I made an inspiration separate from the others and used 'One' as its metaphor.

As looking into five senses of human development, studies about intelligence suggest that short-term memory is changed into long-term memory, and then it can be fixed as knowledge when it is based on sensory memory through sensory experiences. Child development psychologists, such as Piaget and Lowenfeld, presented that five senses were developed in the stages of development emphasizing sensory experiences.

Information about natural and social environments surrounding students remains in our memory through the five senses. Information gathering activities are a starting point of experiences through five senses, and we can be aware of the importance of education about physical sensations.

Activities using senses have a big effect on learning, making it easy to remember, and they are also related to intellectual development. Thus, many psychologists studied on the stages of human
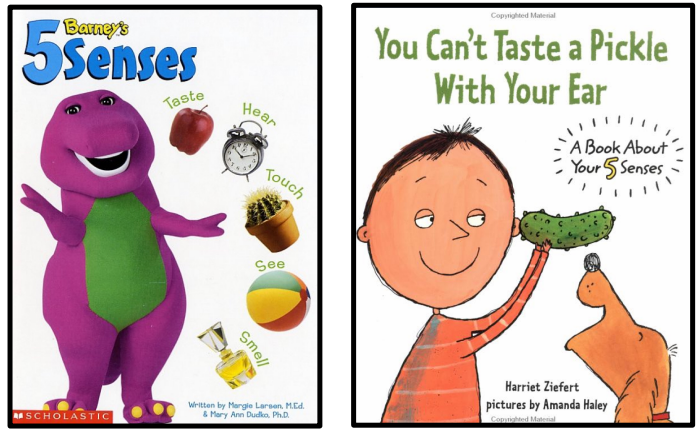

Fig 2. 5 Senses Books 
development underlined direct experiences. Information received through all their physical senses can lead to the intellectual and emotional education. The sensory stimuli, such as sense of sight, hearing, smell, taste, and touch, cause thinking and then build up perception and emotion through thinking processes. Sensory experiences are vital to the training and an emotional development accordingly.

The development of five senses begins at around six months of prenatal stage that brain cells are starting to be formed. In many researches, infants from their birth to 2 years old can distinguish a lot of information because their senses have sharply developed. Children from 4 to 9-year-old continuously learn a concept of conservation of objects through sensory experiences. However, they have sensory abilities like adults after that, so their perceptions have not changed enormously. Rather they classify correctly even complicated and ambiguous stimulations due to their developed searching skills. Also, they can logically organize information and structure perceptions.

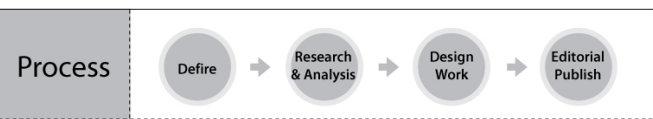

Fig 3. Process of 5 Senses Design Books

\section{Design process}

\section{|l|-1. The sense of sight}

The sense of sight is the first part that contact with objects, and its element of acceptability is higher than other senses. Human beings have vision which makes them recognize different forms since their birth. The more they grow, the more they have strong desires and curiosities about new shapes. The sense of sight is faster in the range of activity and speed of development than other senses. Furthermore, humans have a strong tendency to visualize all knowledge obtained from other senses. We can feel and imagine the sense of hearing, smell, taste, and touch through 'the sense of sight' as well as only we can see. There is a difference between adults and elementary school students in terms of perspectives on looking at the objects. They diversely see things depending on places, locations, environments, and time. On the other hand, adults similarly understand matters that they are watching, even though they didn't see, from same point of view. Because they accumulate their knowledge and experience about matters, their abilities to distinguish things are strong. Consequently, the fact that we can see is a result from experiences all human has.

The sense of sight is a sense of eye to be able to recognize shape and color of objects. 2. Movements of nerves in order to see subjects or things. We all know locations and motions in a space as well as a size, form, light, and brightness of articles. The retina is at the back of eyes is only the area which receives lights, despite eyes are visual organs. The others are no more than clearance devices to help lights reach to the retina accurately. I arranged visual elements using illustrations and typography in various ways based on the scientific evidence.

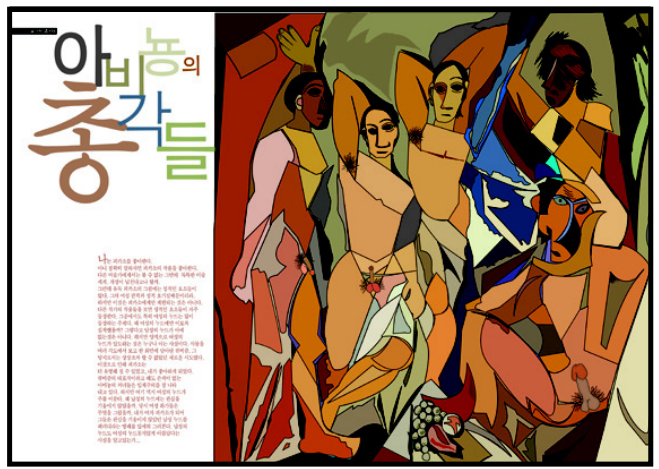

Fig 4. Inside page - The Sense of Sight 
The visual construction and experiment is composed of the definition of sense of sight, scientific structure of eyes, short story of eyesight, common-senses about eyes, color tests, mutual relation between arts and sense of sight, and interviews on sight (about thirty persons).

\section{III-2. The Sense of Hearing}

The sense of hearing and eyesight are first developed among other sense organs. Hearing development of elementary school students make them not only can simply express their feeling about the sounds, but also represent sensuous response of musical experience in the abstract thing. The ability, visualizing voices and music, affects that progress. Also hearing has an effect on controlling brain waves. When we listen to peaceful music or sounds of nature, the brain waves are stabilized and then our imagination and creativity are stimulated.

For those reasons, a hearing stimulation is used a lot in elementary school. The route of sound: vibrations of air travel via an earflap, an ear hole, and finally vibrate the eardrum. This vibration is amplified by three bones in the middle of the ear, and goes to the internal ear going through the oval window. In other words, as the bones in the middle ear touch the oval window connected to the internal ear, a watery liquid in a cochlea is vibrated. As the fluid moves, thousand of "hair cells" are set in motion, and convert that motion into electrical signals which help the sounds go into an auditory nerve. I made the path and perception of hearing visualized as results of experiments.

The sense of hearing consists of an essay, definition of hearing, construction of ears and routs of sounds, waves of sound, units of sound, history of telephone, sounds and proverbs, scientific experiments on the way of sound, personal opinions about hearing, and some interviews on hearing (about twenty five persons).

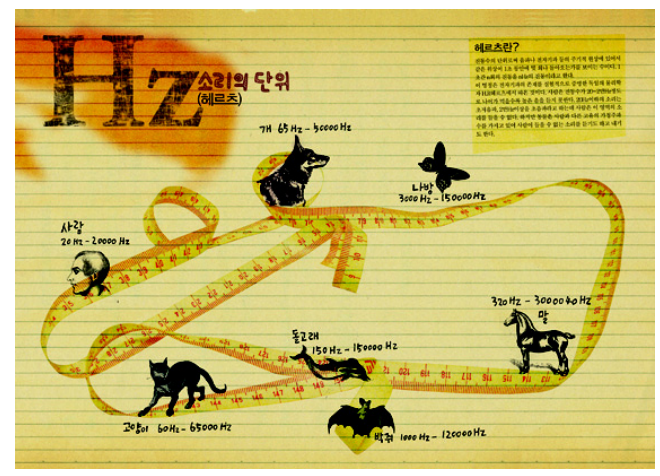

Fig 5. Inside page - The Sense of Hearing

\section{|l|-3.The Sense of Smell}

Olfaction is the sense of smell occurred by stimulation of the cells of nasal and from the particles of chemicals having smell in the air and nasal organ is nose. It is also known as molecule detectors because of a particular odor of gas molecules. The sensibility of odor senses is in proportion to speed of its running on an epithelial cell and its concentration. The Smell is easily tired by continuing stimulations, but it responds to different ones. The sense of smell is usually working with the sense of taste. It also gives emotional factors in both beneficial and harmful substances. We are likely to remember beneficial substances as good odors, but conversely harmful substances as bad ones.

A newborn baby reacts to odors only a few days after their birth. That is the reason babies can recognize the smell of their mother. The sensibility of odor senses isn't developed along ages rather than diminished. However, it helps creativity increased by being foundations of remembered information. Therefore, we can utilize nasal stimulations for activities to express students' various sensitivities. 
Nothing in the map of cerebrum sense has larger sense area than hands that can feel a touch followed by mouth and tongue. Accordingly, I expressed relation to stimulation of tastes feel flavors as well.

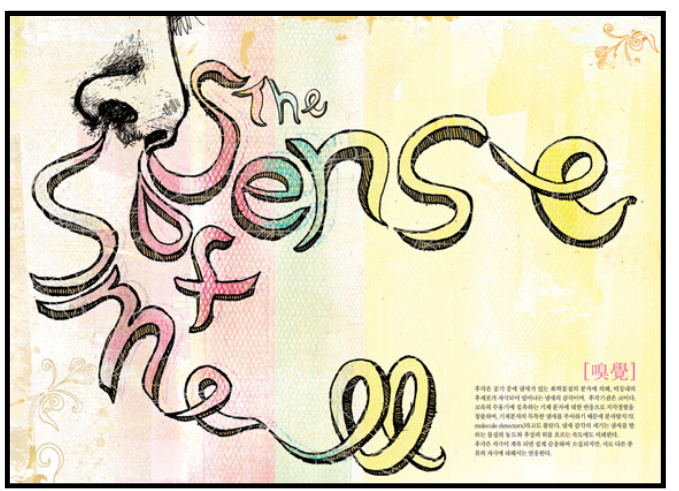

Fig 6. Inside page - The Sense of Smell

The sense of smell is made up an essay on smell, definition of smell, construction of nose, a path of smell molecules, 1.a mission of laboratory, 2. If you lose the sense of smell, you might lose your sense of taste. 3. If you lose the smell, as the smell experiments, a relation among nose, nose drippings and nosebleed, many episodes of the smell, designers' opinions on the smell, interviews of the smell (about twenty nine persons).

\section{|l|-4.The Sense of Taste}

The sense of taste is feeling the taste by tongue, the mouth and contact with taste receptors. People recognize tastes from taste buds that are small structures next to appendixes on the surface of the tongue. Taste cells in taste buds stimulate substances have tastes, and then it informs to the cerebrum, finally, we can feel the taste. I expressed it as information design. I was working photos ; have changing of tongue shape, closely using illustration. We can largely see colors such as orange and pink are related to stimulative favors and colors according to questions. The four pure elements of taste perception are sweet, bitter, salty, and sour. Savory is a sort of pain rather than the sense of taste. I also made the process of experiments visualized. It is inserted that illustrations tell the information we feel sweet at the tip of tongue, bitter at the back of it, sour is on the sides of it, and salty is on the whole surface of tongue. Only bitter is delivered to the cerebrum through the pharyngeal plexusdirectly, and the others go through tongue nerve. Also I made it visualized.

Our sensitive experiences which are called "a taste" are actually flavors combined the taste and smell. In fact, if we hold our nose, we can't feel its taste. The taste of buds is developed until two or three years old, but after that the number of those is decreased much faster and less than the other senses. Consequently, I suggest the study an effortdevelops ability of taste continuously is vital forever.

The sense of taste is consist of the taste essay, definition of the taste, construction of tongue, path of the taste, analysis of five tastes, the taste experiment of emotions and tastes at taste laboratory, results, conclusions drawn, comparison each regional representative foods' tastes, common-senses and episodes of the taste, opinions of designers on the taste and interview of the taste (about twenty eight persons).

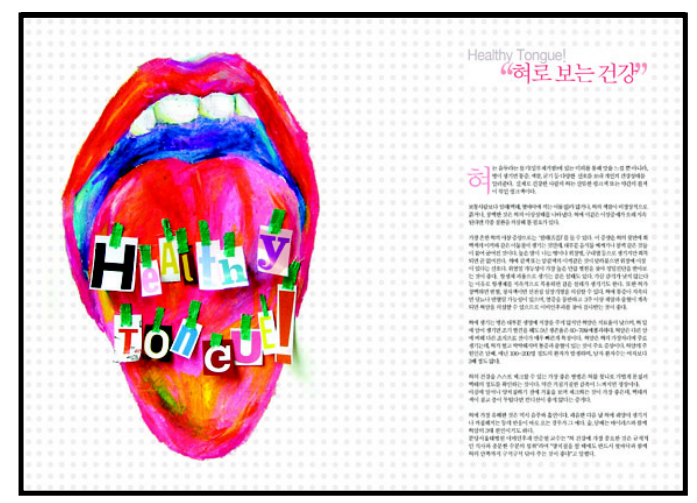

Fig 6. Inside page - The Sense of Taste 


\section{III-5.The Sense of Touch}

The sense of touch is the feeling when other things touch the skin and is one of the five senses which Aristotle defined. The skin feel temperature and pain. We can feel by movement of hairs or tissues such as transformation and twist of skin and mucosa. It is the most sensitive sense.

The sense of touch and notices various properties of surfaces when we touch them. In other words, we can learn the properties of them and recognize them by touching. Skin sensations including pain perception, pressure, sense of cool and hot, and also matiaereu we can also be felt through the sense of sight with the sight experience.

Playing with our hands is good to encourage brain development regardless of the time period if we move our hands from infancy to elementary school. The touch is completed by developing muscles as they grow. Soft and warm touch helps emotional stability for infants and elementary school students. Even little stimulation is communicated well enough to the brain due to the skin connecting to brain through the nervous system. That is the reason for a lot of sense experiences, such as cold and hot, soft and rough and so on, for leads to improvement the brain's ability.

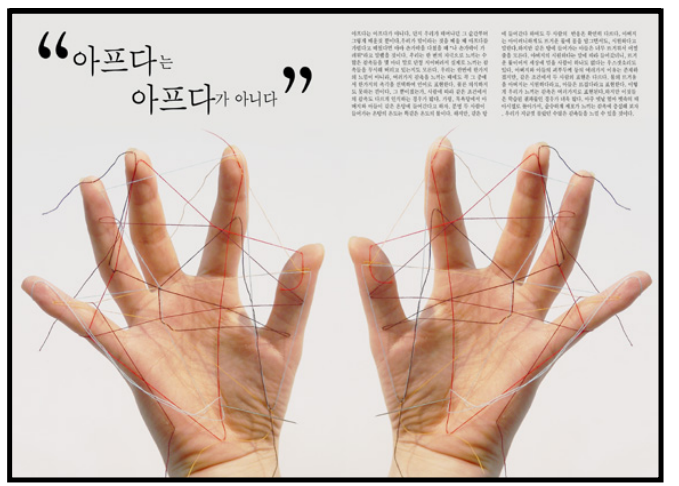

Fig 7. Inside page - The Sense of Touch
Physical contact of love is outstanding among the results of questions on expressions of the touch. It shows women's breast is the most sensitive part. Therefore, using lemons as a metaphor is one of good editorial designs because it is pretty difficult to express.

The sense of touch consists of the essay on the touch, the definition of the touch, the construction of hands communicate the sense of touch, the Braille, the orders of senses on the skin, skin diseases, the touch laboratory, common-senses and episodes of the touch, the love and physical contact, opinions of designers on the touch, interviews about the touch (about twenty four persons)

\section{III-6. Inspiration}

An inspiration is mainly occurred while arts are being created. It is produced suddenly the way creators' experiences can't explain about its accurate motive or how it could have been produced. We can see the similar fact in processes of inventions or discoveries, and say the breakthrough development of insight, come up with solutions unexpectedly. As a result, I made it visualized as an exclamation mark, not a question mark.

Generally they consider it as by inspiration, when people have an experience, they have difficult to explain what it is high value for them. For example, there are Superman who is a symbol of superpower because he has an inspiration, and Batman, human wants to have an inspiration, lives as a superman.

Gesyutalteu Psychology say inspiration is working as "silent organization" that the principle of condensation does not depend on experiences anymore. In Stimulus response psychology, if regular responses continue, it controls responses, so finally new response mechanisms are made. However, those are in sufficient to explain the inspiration. 


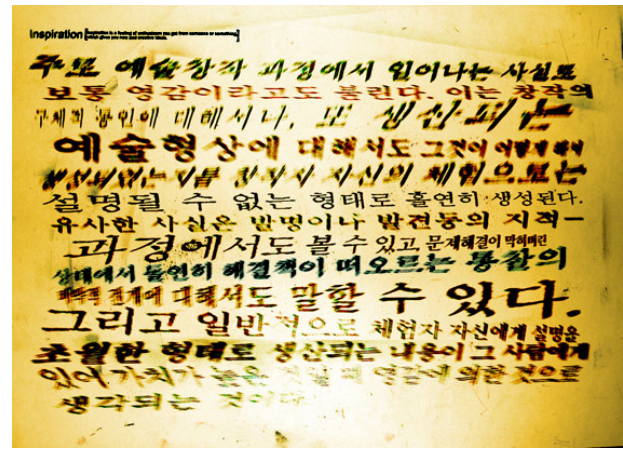

Fig 4. Inside page - Inspiration

Consequently, I expressed them as an illustration. I used imaginations of the brain by using marbling's and graphs of brain waves.

The inspiration consists of the essay of inspiration, the definition of inspiration, the inspiration is strong impression of soul, brain waves and inspirations, the surveys on where are the inspirations from, dreams and telepathies, episodes of inspirations, the relation between arts and inspirations, opinions of various designers about inspirations, interviews of inspiration (about seventeen persons).

\section{IV. the Result of design}

This book has pieces can stimulate experimental inspirations. I was trying to make emotions visualized to show clearly areas of emotions that can help to understand the moment, people recognizes the senses. Also I selected most materials that we can easily feel and find to make people can feel friendly. Although both analog and digital works are in this book, I concentrated on show hand working would be more stressed. The works are harmonies of illustrations and typographies. As a result of arrangements of image sand texts that I've focused, finally images can be 'read' and texts can be 'seen'. In addition, all of them express the belief of themselves with meaning. The book is not just a gesture to show, but a mark that help us understand ourselves in the world. I'd

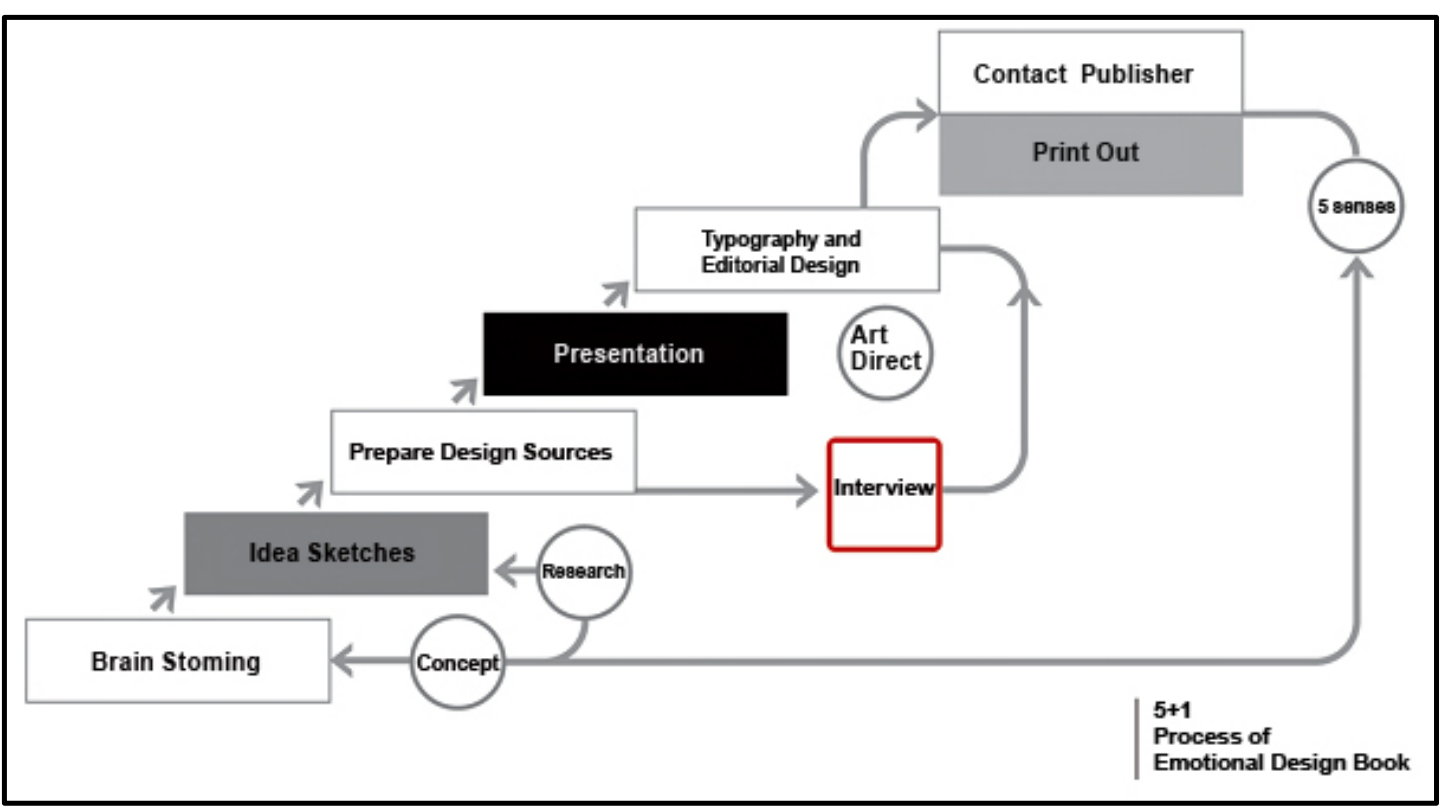

Fig 5. Process of $5+1$ 
lead whole the bulky works, and finally finished all prints, making expression of the five senses and an inspiration visualized. There are only left harsh critics and encouragement of readers. For reference, " $5+1$ (Five Plus One)" is listed in 2007 TOKYO TDC, International Typography Annual.

\section{참 고 문 헌}

[1] D. S. Hong, 5+1 Five plus One, Press Jungle, 2005

[2] D. S. Hong," "Editorial Design for 5 Senses and Intuition Through the Creative Processes," Journal of Korean Society of Design Science, Vol.21, No.6, pp.73-78, 2008.

[3] B. Micheal. D. William, H. Steven, and H, DK, Looking Closer 2, Allworth Press, 1997.

[4] B. Micheal, D. William, H. Steven, and H. DK, Looking Closer 2, Allworth Press, 1997.

[5] F. Edward, Letters on America Laurence King Publishing, 2000.

[6] W. Richard, Art Directors Annual 81, RotoVision, 2002.

[7] W. Youhong "A Study on the Vernacular Trends of Typography," Journal of Korean Society of Design Science, Vol.14, pp225-234, 2001.

[8] C. Jencks, What is Post Modernism?. Seoul: Chungram Edition, 1995.

[9] P, Meggs, A History of Graphic Design, New York: Van Nostrand Reinhold, 1983.

[10] M. S. Kim, Criticism on Modern Design, Ahn Graphics, 1997.

\section{저 자 소 개}

홍 동 식(Hong, Dong-Sik)

정회원

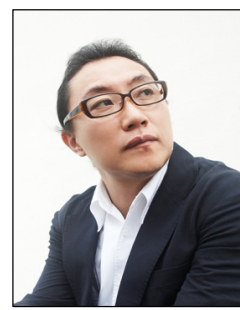

학과 부교수
- 2009년 3월 현재 : 부경대학교 디자인학부 교수

<관심분야> : 시각디자인, 타이포그라피, 편집디자인
- 1990년 2월 : 경북대학교 미술학 과(미술사)

- 1997년 9월 : Academy of Art College(MFA)

- 1998년 3월 2009년 2월 : 동명 대학교 디자인대학 시각디자인 